\title{
Benefits and harms of antidiabetic agents in patients with diabetes and heart failure: systematic review
}

\author{
Dean T Eurich, research associate, ${ }^{1}$ Finlay A McAlister, associate professor, ${ }^{2}$ David F Blackburn, assistant \\ professor, ${ }^{3}$ Sumit R Majumdar, associate professor, ${ }^{2}$ Ross T Tsuyuki, professor, ${ }^{4}$ Janice Varney, librarian, ${ }^{1}$ \\ Jeffrey A Johnson, professor ${ }^{5}$
}

${ }^{1}$ Institute of Health Economics, Edmonton, AB, Canada, T5J 3N4

${ }^{2}$ Division of Internal Medicine, Department of Medicine,

Faculty of Medicine and Dentistry, 2F1 WMC, University of Alberta

Hospital, Edmonton, $A B$ Canada, T6G 2B7

${ }^{3}$ College of Pharmacy and Nutrition, University of

Saskatchewan, Saskatoon, SK, Canada, S7N 5C9

${ }^{4}$ Division of Cardiology, Department of Medicine, Faculty of Medicine and Dentistry, 2F1 WMC, University of Alberta Hospital, Edmonton, $A B$,

Canada, T6G 2B7

${ }^{5}$ Department of Public Health Sciences, Faculty of Medicine and Dentistry, University of Alberta, Edmonton, AB, Canada, T6G 2G3

Correspondence to: J A Johnson jeff.johnson@ualberta.ca

doi:10.1136/bmi.39314.620174.80
Web references w1-w8 are on bmj.com

\section{ABSTRACT}

Objective To review the literature on the association between antidiabetic agents and morbidity and mortality in people with heart failure and diabetes.

Design Systematic review and meta-analysis of controlled studies (randomised trials or cohort studies) evaluating antidiabetic agents and outcomes (death and admission to hospital) in patients with heart failure and diabetes.

Data sources Electronic databases, manual reference search, and contact with investigators.

Review methods Two reviewers independently extracted data. Risk estimates for specific treatments were abstracted and pooled estimates derived by metaanalysis where appropriate.

Results Eight studies were included. Three of four studies found that insulin use was associated with increased risk for all cause mortality (odds ratio 1.25, 95\% confidence interval 1.03 to $1.51 ; 3.42,1.40$ to 8.37 in studies that did not adjust for diet and antidiabetic drugs; hazard ratio $1.66,1.20$ to $2.31 ; 0.96,0.88$ to 1.05 in the studies that did). Metformin was associated with significantly reduced all cause mortality in two studies (hazard ratio $0.86,0.78$ to 0.97 ) compared with other antidiabetic drugs and insulin; $0.70,0.54$ to 0.91 compared with sulfonylureas); a similar trend was seen in a third. Metformin was not associated with increased hospital admission for any cause or for heart failure specifically. In four studies, use of

thiazolidinediones was associated with reduced all cause mortality (pooled odds ratio $0.83,0.71$ to $0.97, \mathrm{I}^{2}=52 \%$, $\mathrm{P}=0.02$ ). Thiazolidinediones were associated with increased risk of hospital admission for heart failure (pooled odds ratio 1.13 (1.04 to 1.22 ), $\mathrm{I}^{2}=0 \%, \mathrm{P}=0.004$ ). The two studies of sulfonylureas had conflicting results, probably because of differences in comparator treatments. Important limitations were noted in all studies.

Conclusion Metformin was the only antidiabetic agent not associated with harm in patients with heart failure and diabetes. It was associated with reduced all cause mortality in two of the three studies.

\section{INTRODUCTION}

Worldwide, more than 171 million people have diabetes, and its prevalence is expected to double by $2030 .{ }^{1}$ People with diabetes are at increased risk of developing heart failure, ${ }^{23}$ with the relative risk increasing by 10-15\% per unit increase in glycated haemoglobin. ${ }^{4-7}$ Conversely, heart failure is present in 25-40\% of all adults with diabetes. ${ }^{28-12}$ Moreover, people with heart failure have worse outcomes if they also have diabetes, ${ }^{13-15}$ and it has been suggested that any level of hyperglycaemia is associated with increased rates of hospital admission, even in patients without manifest diabetes. ${ }^{16}$

How best to achieve glycaemic control in patients with diabetes and heart failure is therefore an important clinical question. Many antidiabetic drugs are now available to control hyperglycaemia. However, their role in managing diabetes in patients with heart failure is uncertain, ${ }^{17}$ and considerable controversy exists about the overall effect of antidiabetic agents on outcomes in people with comorbid diabetes and heart failure. ${ }^{\mathrm{w} 1 \mathrm{w} 2}$ Even the level of optimal glucose control in patients with diabetes and heart failure remains uncertain, and some evidence suggests that tight glycaemic control (glycated haemoglobin $\leq 7 \%$ ) may be associated with worse survival than less tight control in patients with heart failure, irrespective of the agent used. ${ }^{18}$ As a result, outcomes are possibly affected not only by the choice of antidiabetic agent, but also by the degree of glycaemic control achieved with the agent.

Because of the lack of evidence around these matters, current recommendations are based on pathophysiological rationale, clinical experience, and expert consensus. A better understanding of the effects of antidiabetic agents on the health of people with heart failure and diabetes is needed. ${ }^{17}$ Thus, we conducted a systematic review to examine the relation between antidiabetic treatment and outcomes in people with heart failure and diabetes.

\section{METHODS}

We used a comprehensive search strategy of various electronic databases (Medline (1966-2007), HealthSTAR (1966-2007), Embase (1980-2007), Cumulative Index to Nursing and Allied Health Literature (1982-2007), International Pharmaceutical Abstracts (1970-2007), Allied and Complementary Medicine (1985-2007), Cochrane Central Register of Controlled Trials (1991-2007), and the Web of Science (1900-2007)) from their date of inception until the 
week of 16 July 2007 for studies with contemporaneous comparison groups (such as randomised controlled trials or cohort studies) that evaluated the association between antidiabetic agents and clinical outcomes of hospital admission or mortality (or both) in patients with diabetes and heart failure (appendix on www.achord.ca). In addition, we also manually searched reference lists from original studies and review articles and contacted experts and authors of included studies. The search was not restricted by language or quality of study. We did not assess the risk of developing heart failure associated with antidiabetic drugs.

Two reviewers (DTE and DFB) independently identified relevant citations and included them if they described original research, included subjects with both diabetes and heart failure, evaluated the effects of antidiabetic agents on health outcomes (mortality, all cause hospital admission, and hospital admission for heart failure), and included a contemporaneous control group for comparison. Discrepancies were resolved by consensus after review by a third investigator (JAJ). All data were extracted and DTE and DFB independently assessed the methodological quality of included studies using a



Fig 1| QUOROM diagram of systematic search validated quality checklist. ${ }^{19}$ The maximum score on the quality checklist is 32 , with a score of $12(38 \%)$ or greater considered to be acceptable quality. ${ }^{1920}$

\section{Statistical analysis}

To summarise the effects of antidiabetic drugs on outcomes of interest (all cause mortality or hospital admission), we abstracted the risk estimates and 95\% confidence intervals from each study. For studies with insufficient information, we contacted the primary study authors to acquire and verify data where possible. If appropriate, we then pooled data across studies using random effects models if excessive statistical heterogeneity did not exist (measured using the $\mathrm{I}^{2}$ statistic and defined a priori as $\mathrm{P} \leq 0.10$ or $\left.\mathrm{I}^{2} \geq 50 \%\right) .{ }^{21} \mathrm{We}$ used Cochrane Review Manager 4.2 for all analyses.

\section{RESULTS}

Our search yielded 10091 citations, and eight studies met our inclusion criteria - one randomised controlled trial, two post hoc subgroup analyses from randomised trials, four retrospective cohort studies, and one prospective cohort study (fig 1). ${ }^{\text {w-w8 }}$ Interobserver agreement was $\kappa=0.84$ for study inclusion.

Of the eight studies, three had more than two comparison groups. As a result, four studies evaluated the effect of insulin treatment in patients with heart failure ( $\mathrm{n}=9104)$, three examined metformin $(\mathrm{n}=3327)$, four evaluated thiazolidinediones $(\mathrm{n}=3409)$, and two studies $(n=8918)$ compared sulfonylureas with other agents. No studies specifically evaluated the effects of alpha glucosidase inhibitors (such as acarbose and meglitol) or non-sulfonylurea insulin secretagogues (such as repaglinide and nateglinide) in patients with heart failure. The box and table 1 summarise the eight studies and their key findings. Overall, the studies were of acceptable quality, with a methodological quality score ranging from $13(41 \%)$ to $22(69 \%)$ (box); the median quality score was $16(50 \%)$.

Table 2 summarises the statistical heterogeneity of the studies. A formal meta-analysis was not performed for the effects of insulin or metformin on all cause mortality because of significant statistical heterogeneity. With respect to hospital admission, meta-analyses could only be interpreted for the effects of metformin on all cause hospital admission and thiazolidinediones on hospital admission for heart failure (table 2).

\section{Insulin}

Outcomes with insulin were evaluated in a subgroup analysis of 496 patients with diabetes and left ventricular dysfunction (ejection fraction $<40 \%$ after acute myocardial infarction) from the survival and ventricular enlargement (SAVE) trial (box). ${ }^{\text {w6 }}$ After multivari ate adjustment, compared with 328 patients not treated with insulin (but treated with diet, sulfonylurea, or metformin), the 168 patients treated with insulin had significantly increased risk of all cause mortality (adjusted hazard ratio $1.66,95 \%$ confidence interval 1.20 to 2.31), and cardiovascular morbidity (hospital admission for heart failure or prescription of an open label 
Table 1 | Results of studies assessing antidiabetic agents in the treatment of diabetes in patients with heart failure

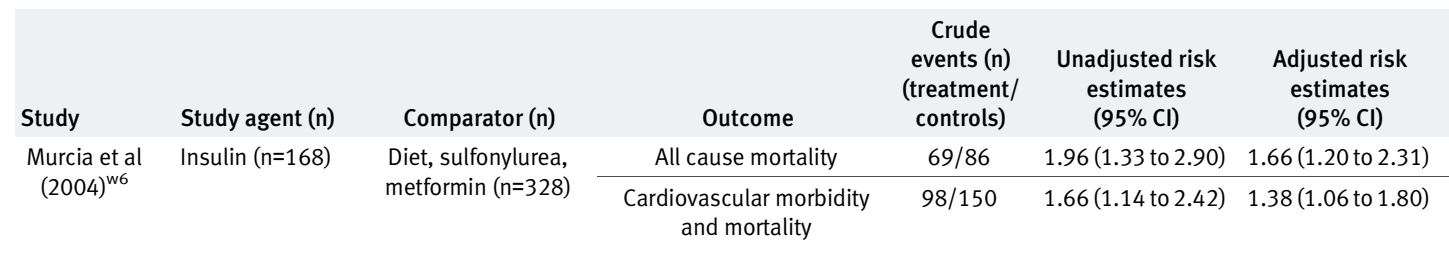

\begin{tabular}{|c|c|c|c|c|c|c|}
\hline \multirow[t]{2}{*}{$\begin{array}{c}\text { Pocock et al } \\
(2006)^{w 4}\end{array}$} & \multirow[t]{2}{*}{ Insulin $(n=706)$} & \multirow{2}{*}{$\begin{array}{l}\text { Diet, sulfonylurea, } \\
\text { metformin, } \\
\text { thiazolidinediones } \\
(n=1454)\end{array}$} & All cause mortality & $245 / 435$ & $1.25(1.03$ to 1.51$)$ & $\begin{array}{c}\text { No adjusted } \\
\text { estimate }\end{array}$ \\
\hline & & & $\begin{array}{l}\text { Death from cardiovascular } \\
\text { disease or hospital } \\
\text { admission for heart failure }\end{array}$ & $367 / 598$ & 1.55 (1.29 to 1.86$)$ & $\begin{array}{l}\text { No adjusted } \\
\text { estimate }\end{array}$ \\
\hline
\end{tabular}

Patients with diabetes who survive a myocardial infarction with left ventricular dysfunction are at increased risk of subsequent mortality or cardiovascular events. Patients treated with insulin are at higher risk than those given other antidiabetic agents

In patients with systolic dysfunction and with preserved systolic function, the presence of diabetes and diabetes treated with insulin was highly prognostic of all cause mortality, death from cardiovascular disease, or hospital admission for heart failure

\begin{tabular}{|c|c|c|c|c|c|c|c|}
\hline \multirow[t]{2}{*}{$\begin{array}{l}\text { Smooke et al } \\
(2006)^{\text {w5 }}\end{array}$} & \multirow[t]{2}{*}{ Insulin $(n=43)$} & \multirow{2}{*}{$\begin{array}{l}\text { Diet, sulfonylurea, } \\
\text { metformin, } \\
\text { thiazolidinediones } \\
\quad(n=89)\end{array}$} & $\begin{array}{c}\text { All cause mortality at } \\
1 \text { year }\end{array}$ & $13 / 10$ & 3.42 (1.40 to 8.37$)$ & $\begin{array}{l}\text { No adjusted } \\
\text { estimate }\end{array}$ & \multirow{2}{*}{$\begin{array}{l}\text { Insulin was associated with a pronounced } \\
\text { increase in mortality. No increased risk } \\
\text { of mortality was seen for } \\
\text { non-insulin treated diabetes }\end{array}$} \\
\hline & & & $\begin{array}{c}\text { All cause mortality at } \\
2 \text { years }\end{array}$ & $14 / 16$ & $2.20(0.96$ to 5.03$)$ & $\begin{array}{l}\text { No adjusted } \\
\text { estimate }\end{array}$ & \\
\hline $\begin{array}{l}\text { Masoudi et al } \\
(2005)^{\mathrm{w} 1}\end{array}$ & Insulin $(n=8187)$ & $\begin{array}{l}\text { Sulfonylurea, non- } \\
\text { sulfonylurea } \\
\text { secretagogues, alpha } \\
\text { glucosidase inhibitors, } \\
\text { metformin, TZDs } \\
(n=8230)\end{array}$ & $\begin{array}{c}\text { All cause mortality at } \\
1 \text { year }\end{array}$ & $2891 / 2637$ & $1.16(1.09$ to 1.24$)$ & 0.96 (0.88 to 1.05$)$ & $\begin{array}{l}\text { Insulin was not associated with an } \\
\text { increased risk of mortality }\end{array}$ \\
\hline $\begin{array}{l}\text { Inzucchi et al } \\
(2005)^{\text {w3 }}\end{array}$ & $\begin{array}{l}\text { Metformin } \\
(n=406)\end{array}$ & $\begin{array}{l}\text { Sulfonylurea, non- } \\
\text { sulfonylurea } \\
\text { secretagogues, alpha } \\
\text { glucosidase inhibitors, } \\
\text { insulin }(n=2184)\end{array}$ & $\begin{array}{l}\text { All cause mortality at } \\
1 \text { year }\end{array}$ & $93 / 768$ & 0.55 (0.43 to 0.70$)$ & 0.92 (0.72 to 1.18$)$ & $\begin{array}{l}\text { In the subgroup of patients with left } \\
\text { ventricular dysfunction, metformin } \\
\text { did not increase the risk of mortality }\end{array}$ \\
\hline \multirow[t]{3}{*}{$\begin{array}{l}\text { Masoudi et al } \\
(2005)^{\mathrm{w} 1}\end{array}$} & \multirow[t]{3}{*}{$\begin{array}{l}\text { Metformin } \\
(n=1861)\end{array}$} & \multirow{3}{*}{$\begin{array}{l}\text { Sulfonylurea, non- } \\
\text { sulfonylurea } \\
\text { secretagogues, alpha } \\
\text { glucosidase inhibitors, } \\
\text { insulin) (n=12 069) }\end{array}$} & $\begin{array}{l}\text { All cause mortality at } \\
1 \text { year }\end{array}$ & $460 / 4345$ & $0.58(0.52$ to 0.65$)$ & $0.86(0.78$ to 0.97$)$ & \multirow{3}{*}{$\begin{array}{l}\text { Metformin was associated with reduced } \\
\text { mortality, all cause hospital admission, } \\
\text { and heart failure related hospital } \\
\text { admission. Metformin did not increase } \\
\text { the risk for hospital admission for } \\
\text { lactic acidosis }\end{array}$} \\
\hline & & & $\begin{array}{l}\text { All cause hospital } \\
\text { admission at } 1 \text { year }\end{array}$ & $1265 / 8702$ & 0.82 (0.74 to 0.91$)$ & 0.94 (0.89 to 1.01$)$ & \\
\hline & & & $\begin{array}{l}\text { Readmission for heart } \\
\text { failure at } 1 \text { year }\end{array}$ & $1091 / 7821$ & $0.52(0.57$ to 0.48$)$ & 0.92 (0.86 to 0.99$)$ & \\
\hline \multirow[t]{6}{*}{$\begin{array}{l}\text { Eurich et al } \\
(2005)^{\mathrm{w} 2}\end{array}$} & \multirow{6}{*}{$\begin{array}{l}\text { Metformin } \\
\text { monotherapy } \\
(n=208)\end{array}$} & \multirow[t]{6}{*}{$\begin{array}{c}\text { Sulfonylurea } \\
\text { monotherapy }(n=773)\end{array}$} & $\begin{array}{l}\text { All cause mortality at } \\
1 \text { year }\end{array}$ & $29 / 200$ & $0.43(0.29$ to 0.65$)$ & 0.66 (0.44 to 0.97$)$ & \multirow{6}{*}{$\begin{array}{c}\text { Metformin was associated with reduced all } \\
\text { cause mortality and a trend towards } \\
\text { reduced risk of all cause hospital } \\
\text { admission }\end{array}$} \\
\hline & & & $\begin{array}{l}\text { All cause mortality at study } \\
\text { end }\end{array}$ & $69 / 404$ & $0.40(0.29$ to 0.56$)$ & $0.70(0.54$ to 0.91$)$ & \\
\hline & & & $\begin{array}{l}\text { All cause hospital } \\
\text { admission at } 1 \text { year }\end{array}$ & $102 / 406$ & 0.87 (0.64 to 1.18$)$ & 0.84 (0.67 to 1.04$)$ & \\
\hline & & & $\begin{array}{l}\text { All cause hospital } \\
\text { admission at study end }\end{array}$ & $143 / 538$ & $0.96(0.69$ to 1.34$)$ & 0.87 (0.73 to 1.05$)$ & \\
\hline & & & $\begin{array}{l}\text { Combined all cause } \\
\text { mortality or hospital } \\
\text { admission at } 1 \text { year }\end{array}$ & $115 / 480$ & $0.76(0.55$ to 1.03$)$ & 0.79 (0.65 to 0.98$)$ & \\
\hline & & & $\begin{array}{l}\text { Combined all cause } \\
\text { mortality or hospital } \\
\text { admission at study end }\end{array}$ & $160 / 658$ & 0.58 (0.40 to 0.85$)$ & 0.83 (0.70 to 0.99$)$ & \\
\hline \multirow[t]{6}{*}{$\begin{array}{l}\text { Eurich et al } \\
(2005)^{\text {w2 }}\end{array}$} & \multirow{6}{*}{$\begin{array}{l}\text { Metformin and } \\
\text { sulfonylurea } \\
\text { combination } \\
\text { therapy }(\mathrm{n}=852)\end{array}$} & \multirow[t]{6}{*}{$\begin{array}{c}\text { Sulfonylurea } \\
\text { monotherapy }(n=773)\end{array}$} & $\begin{array}{c}\text { All cause mortality at } \\
1 \text { year }\end{array}$ & $97 / 200$ & 0.34 (0.26 to 0.44$)$ & $0.54(0.42$ to 0.70$)$ & \multirow{6}{*}{$\begin{array}{l}\text { Metformin plus sulfonylurea was } \\
\text { associated with reduced all cause } \\
\text { mortality and a trend towards reduced } \\
\text { risk of all cause hospital admission. } \\
\text { Metformin was not associated with an } \\
\text { increased risk of lactic acidosis }\end{array}$} \\
\hline & & & $\begin{array}{l}\text { All cause mortality at study } \\
\text { end }\end{array}$ & $263 / 404$ & $0.36(0.30$ to 0.45$)$ & 0.61 (0.52 to 0.72$)$ & \\
\hline & & & $\begin{array}{l}\text { All cause hospital } \\
\text { admission at } 1 \text { year }\end{array}$ & $435 / 406$ & 0.94 (0.78 to 1.15$)$ & 0.92 (0.80 to 1.06$)$ & \\
\hline & & & $\begin{array}{l}\text { All cause hospital } \\
\text { admission at study end }\end{array}$ & $632 / 538$ & $1.26(1.01$ to 1.56$)$ & 0.93 (0.83 to 1.05$)$ & \\
\hline & & & $\begin{array}{l}\text { Combined all cause } \\
\text { mortality or hospital } \\
\text { admission at } 1 \text { year }\end{array}$ & $480 / 480$ & $0.79(0.65$ to 0.96$)$ & $0.86(0.75$ to 0.98$)$ & \\
\hline & & & $\begin{array}{l}\text { Combined all cause } \\
\text { mortality or hospital } \\
\text { admission at study end }\end{array}$ & $681 / 658$ & $0.70(0.54$ to 0.90$)$ & $0.86(0.77$ to 0.96$)$ & \\
\hline
\end{tabular}




\begin{tabular}{|c|c|c|c|c|c|c|c|}
\hline \multirow[t]{2}{*}{$\begin{array}{l}\text { Inzucchi et al } \\
(2005)^{\text {w3 }}\end{array}$} & \multirow[t]{2}{*}{ TZD (n=255) } & \multirow{2}{*}{$\begin{array}{l}\text { Sulfonylurea, non- } \\
\text { sulfonylurea } \\
\text { secretagogues, alpha } \\
\text { glucosidase inhibitors, } \\
\text { insulin }(n=2184)\end{array}$} & $\begin{array}{l}\text { All cause mortality at } \\
1 \text { year }\end{array}$ & $92 / 768$ & $0.60(0.54$ to 0.65$)$ & 1.04 (0.83 to 1.31$)$ & \multirow{2}{*}{$\begin{array}{c}\text { In the subgroup of patients with left } \\
\text { ventricular dysfunction, TZDs did not } \\
\text { increase the risk of mortality. There was a } \\
\text { trend towards increasing risk for heart } \\
\text { failure related hospital admission for TZD } \\
\text { therapy }\end{array}$} \\
\hline & & & $\begin{array}{l}\text { Readmission for heart } \\
\text { failure at } 1 \text { year }\end{array}$ & $139 / 1083$ & $1.22(0.94$ to 1.58$)$ & $1.15(0.97$ to 1.38$)$ & \\
\hline \multirow[t]{3}{*}{$\begin{array}{l}\text { Masoudi et al } \\
2005^{\mathrm{w} 1}\end{array}$} & \multirow[t]{3}{*}{ TZD $(n=2226)$} & \multirow{3}{*}{$\begin{array}{l}\text { Sulfonylurea, non- } \\
\text { sulfonylurea } \\
\text { secretagogues, alpha } \\
\text { glucosidase inhibitors, } \\
\text { insulin ( } \mathrm{n}=12069 \text { ) }\end{array}$} & $\begin{array}{l}\text { All cause mortality at } \\
1 \text { year }\end{array}$ & $670 / 4345$ & 0.77 (0.69 to 0.84$)$ & 0.87 (0.80 to 0.94$)$ & \multirow{3}{*}{$\begin{array}{c}\text { TZD was associated with reduced } \\
\text { mortality. No effect was seen on all cause } \\
\text { hospital admission and a trend towards } \\
\text { increased risk for heart failure related } \\
\text { hospital admission }\end{array}$} \\
\hline & & & $\begin{array}{l}\text { All cause hospital } \\
\text { admission at } 1 \text { year }\end{array}$ & $1660 / 8702$ & 1.14 (1.26 to 1.02$)$ & 1.04 (0.99 to 1.10$)$ & \\
\hline & & & $\begin{array}{l}\text { Readmission for heart } \\
\text { failure at } 1 \text { year }\end{array}$ & $1505 / 7821$ & 1.13 (1.03 to 1.25$)$ & $1.06(1.00$ to 1.12$)$ & \\
\hline \multirow[t]{2}{*}{$\begin{array}{l}\text { Dargie et al } \\
(2007)^{\mathrm{w} 7}\end{array}$} & \multirow[t]{2}{*}{ TZD (n=110) } & \multirow[t]{2}{*}{ Placebo $(n=114)$} & $\begin{array}{l}\text { All cause mortality at } \\
1 \text { year }\end{array}$ & $8 / 5$ & 1.71 (0.55 to 5.34$)$ & 1.50 (0.49 to 4.59$)$ & \multirow{2}{*}{$\begin{array}{l}\text { TZD did not adversely affect ejection } \\
\text { fraction, left ventricular volumes, cardiac } \\
\text { index, or transmitral Doppler flow. There } \\
\text { was a trend towards adverse clinical events } \\
\text { with TZD and there was a higher incidence } \\
\text { of fluid related end points during treatment } \\
\text { with TZD }\end{array}$} \\
\hline & & & $\begin{array}{l}\text { Readmission for heart } \\
\text { failure at } 1 \text { year }\end{array}$ & $5 / 4$ & 1.31 (0.34 to 4.99$)$ & $\begin{array}{l}\text { Relative risk } 1.30 \\
(0.35 \text { to } 4.82) \text { (no } \\
\text { adjustment } \\
\text { because of trial } \\
\text { design) }\end{array}$ & \\
\hline \multirow[t]{2}{*}{$\begin{array}{l}\text { Aguilar et al } \\
(2007)^{\text {w8 }}\end{array}$} & \multirow[t]{2}{*}{ TZD (n=818) } & \multirow{2}{*}{$\begin{array}{l}\text { Sulfonylurea, non- } \\
\text { sulfonylurea } \\
\text { secretagogues, alpha } \\
\text { glucosidase inhibitors, } \\
\text { insulin }(n=4700)\end{array}$} & $\begin{array}{l}\text { All cause mortality at } \\
2 \text { years }\end{array}$ & $168 / 1192$ & $0.76(0.63$ to 0.91$)$ & 0.98 (0.81 to 1.17$)$ & \multirow{2}{*}{$\begin{array}{l}\text { TZD was not associated with increased risk } \\
\text { of heart failure related hospital admission } \\
\text { or all cause mortality }\end{array}$} \\
\hline & & & $\begin{array}{l}\text { Hospital admission for } \\
\text { heart failure at } 2 \text { years }\end{array}$ & $134 / 741$ & 1.05 (0.86 to 1.28$)$ & $1.00(0.81$ to 1.24$)$ & \\
\hline $\begin{array}{l}\text { Masoudi et al } \\
(2005)^{\mathrm{w} 1}\end{array}$ & $\begin{array}{l}\text { Sulfonylurea } \\
(n=8145)\end{array}$ & $\begin{array}{l}\text { Non-sulfonylurea } \\
\text { secretagogues, alpha } \\
\text { glucosidase inhibitors, } \\
\text { metformin, TZDs, insulin } \\
\qquad(n=8272)\end{array}$ & $\begin{array}{c}\text { All cause mortality at } \\
1 \text { year }\end{array}$ & $2679 / 2849$ & 0.93 (0.87 to 1.00$)$ & $0.99(0.91$ to 1.08$)$ & $\begin{array}{l}\text { Sulfonylurea was not associated with } \\
\text { increase risk of mortality }\end{array}$ \\
\hline
\end{tabular}

angiotensin converting enzyme inhibitor, or myocardial infarction) and mortality $(1.38,1.06$ to 1.80 ; table 1).

The effect of insulin was also evaluated in the CHARM (candesartan in heart failure: assessment of reduction in mortality and morbidity) study (box). ${ }^{22}$ w4 Although insulin was not directly compared with other antidiabetic drugs in adjusted analyses, unadjusted risk ratios calculated from the raw data presented in the paper suggest that treatment with insulin is associated with an increased risk of all cause mortality (risk ratio $1.25,1.03$ to 1.51 ) and death from cardiovascular disease or hospital admission for heart failure $(1.55,1.29$ to 1.86 ) compared with other treatments in patients with diabetes (table 1)..$^{22}$ w

Outcomes with insulin were also assessed in 554 consecutive patients referred to a university medical centre for management of heart failure (box). ${ }^{\mathrm{w} 5}$ Of these patients, $132(24 \%)$ had diabetes and were prospectively followed for 11.7 months. Although insulin and non-insulin treatments were not directly compared in patients with diabetes, extrapolation from the raw data suggests an unadjusted risk ratio for all cause mortality of 3.42 (1.40 to 8.37) at one year and 2.20 (0.96 to 5.03$)$ at two years (table 1$)$ for patients with diabetes treated with insulin compared with those not treated with insulin.

The effects of insulin on mortality were also evaluated in a retrospective cohort study of 16417 Medicare beneficiaries with diabetes who were discharged from hospital with a primary diagnosis of heart failure (box). ${ }^{\mathrm{w} 1}$ Unlike previous studies, this study found no association between the use of insulin and mortality adjusted hazard ratio $0.96 ; 0.88$ to 1.05 ) compared with patients receiving metformin, thiazolidinediones, sulfonylureas, non-sulfonylurea insulin secretagogues, or alpha glycosidase inhibitors (table 1). ${ }^{\mathrm{w}}$

\section{Oral antidiabetic agents}

\section{Metformin}

Outcomes with metformin were evaluated in a retrospective cohort study of Medicare beneficiaries with diabetes discharged after hospital admission for acute myocardial infarction (box). ${ }^{\mathrm{w} 3}$ Subgroup analysis of the patients with diabetes and moderate to severe impaired left ventricular systolic function $(n=2875)$ suggested that after multivariate adjustment treatment with metformin was not associated with any risk of all cause mortality at one year compared with patients receiving sulfonylureas, non-sulfonylurea insulin secretagogues, alpha glucosidase inhibitors, and insu$\operatorname{lin}(\mathrm{n}=406 ; 0.92,0.72$ to 1.18 ; table 1$){ }^{\text {w3 }}$

The study of Medicare beneficiaries with diabetes discharged with a primary diagnosis of heart failure also evaluated the effect of metformin on all cause mortality at one year (box). ${ }^{\mathrm{w} 1}$ After multivariate adjustment, compared with patients not receiving insulin sensitisers (that is, receiving sulfonylureas, non-sulfonylurea insulin secretagogues, alpha glucosidase inhibitors, or insulin) ( $\mathrm{n}=12$ 069), all cause mortality was significantly lower in patients treated with metformin ( $\mathrm{n}=1861 ; 0.86,0.78$ to 0.97$)$, as well as in patients treated both with metformin and thiazolidinediones $(\mathrm{n}=261 ; 0.76,0.58$ to 0.99 ; table 1$)$. In addition, no difference was seen in the risk for all cause hospital readmissions for patients receiving metformin $(0.94,0.89$ to 


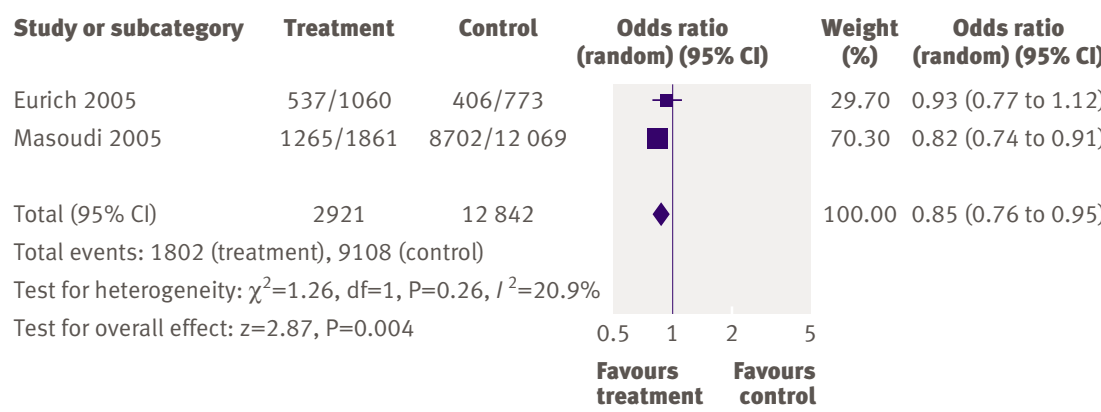

Fig 2 | Pooled odds ratio for metformin compared with other treatments for all cause hospital admission at one year. The data for Eurich 2005 were pooled from the metformin monotherapy group and combination therapy group (pooled test for heterogeneity $\mathrm{P}=0.70 ; \mathrm{I}^{2}=0 \%$ )

1.01) and a lower risk was seen in patients treated with both metformin and thiazolidinediones $(0.82,0.69$ to 0.96; table 1). A lower risk was also seen for metformin users with respect to readmissions related to heart failure $(0.92,0.86$ to 0.99$)$ and a trend towards reduction in patients receiving both metformin and thiazolidinediones $(0.85,0.71$ to 1.01$)$.

In a retrospective analysis using administrative records, another study compared metformin alone, or combined with sulfonylurea, to sulfonylurea monotherapy in 1833 patients with newly treated diabetes and incident heart failure (box). ${ }^{\text {w2 }}$ After multivariate adjustment, all cause mortality was significantly lower with metformin monotherapy $(0.66,0.44$ to 0.97 at one year; $0.70,0.54$ to 0.91 after 2.5 years), or with combined treatment with metformin-sulfonylurea $(0.54$, 0.42 to 0.70 at one year; $0.61,0.52$ to 0.72 after 2 . 5 years; table 1). A reduction in the composite outcome of all cause mortality or hospital admission was also seen at the end of follow-up for the metformin monotherapy group $(0.83,0.70$ to 0.99$)$ and for combination therapy $(0.86,0.77$ to 0.96 ; table 1$)$.

Both of the studies assessing the effect of metformin on all cause hospital admission at one year were of good methodological quality (box) and yielded similar

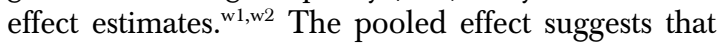
treatment with metformin may be associated with reduced all cause hospital admission at one year compared to other treatments (pooled odds ratio $0.85,0.76$ to $0.95 ; \mathrm{I}^{2}=21 \% ; \mathrm{P}=0.004$; fig 2 ).

\begin{tabular}{|c|c|c|c|c|}
\hline Antidiabetic drug & No of studies & Outcome assessed & $\begin{array}{l}\text { P value for } \\
\text { heterogeneity }\end{array}$ & I2 statistic \\
\hline \multirow{2}{*}{ Insulin } & 4 & All cause mortality & 0.03 & $67.2 \%$ \\
\hline & 0 & All cause hospital admission & Not determined & Not determined \\
\hline \multirow{3}{*}{ Thiazolidinediones } & 4 & All cause mortality & 0.10 & $52.3 \%$ \\
\hline & 1 & All cause hospital admission & Not determined & Not determined \\
\hline & 4 & $\begin{array}{l}\text { Heart failure related hospital } \\
\text { admission }\end{array}$ & 0.82 & $0 \%$ \\
\hline \multirow{2}{*}{ Metformin } & 3 & All cause mortality at 1 year & $<0.001$ & $83.5 \%$ \\
\hline & 2 & $\begin{array}{c}\text { All cause hospitaladmission at } \\
1 \text { year }\end{array}$ & 0.26 & $20.9 \%$ \\
\hline Sulfonylurea & 2 & All cause mortality at 1 year & $<0.001$ & $96.4 \%$ \\
\hline
\end{tabular}

\section{Thiazolidinediones}

In the previous Medicare study of patients with diabetes discharged after hospital admission for acute myocardial infarction, ${ }^{\mathrm{w} 3}$ after multivariate adjustment, the risk of all cause mortality at one year was no different for patients who received thiazolidinediones $(n=255)$ than for patients treated with sulfonylureas, non-sulfonylurea insulin secretagogues, alpha glucosidase inhibitors, or insulin (1.04, 0.83 to 1.31 ; table 1). There was a trend, however, towards an increased risk of readmission for heart failure associated with thiazolidinediones ( $\mathrm{n}=255 ; 1.15,0.97$ to 1.38$).{ }^{\mathrm{w} 3}$

In the second Medicare study of patients with diabetes discharged with a primary diagnosis of heart failure, after multivariate adjustment as above ( $\mathrm{n}=12069)$, all cause mortality at one year was significantly lower for patients treated with thiazolidinediones $(\mathrm{n}=2226$; $0.87,0.80$ to 0.94 ; table 1 ). ${ }^{\mathrm{wl}}$ This study also found no difference in the risk for all cause hospital readmissions for patients receiving thiazolidinediones $(1.04,0.99$ to 1.10). However, a small increased risk of readmission for heart failure was seen in patients receiving thiazolidinediones (1.06, 1.00 to 1.12 ).

In a retrospective cohort study of ambulatory patients followed through Veteran Affairs medical centres (box), after multivariate adjustment no differences were seen in all cause mortality at two years $(n=814$; $0.98,0.81$ to 1.17 ) or in hospital admission for heart failure $(1.00,0.81$ to 1.24 ; table 1$)$ in patients treated with thiazolidinediones compared with those not receiving insulin sensitisers $(n=4700)$. However, in patients not receiving insulin, thiazolidinediones $(n=381)$ were associated with an increased risk of hospital admission for heart failure compared with those not receiving insulin sensitisers $(\mathrm{n}=2217 ; 1.62,1.15$ to 2.29). ${ }^{\text {w8 }}$

The only randomised controlled trial evaluated the addition of rosiglitazone $(n=110)$ or placebo $(n=114)$ to existing antidiabetic agents in patients with New York Heart Association class I or II disease (box). ${ }^{\text {w7 }}$ Although not a specific end point of the study, after 52 weeks of treatment (compared with placebo) there was a trend towards an increased risk of all cause mortality for rosiglitazone (hazard ratio $1.50,0.49$ to 4.59 ) and in the proportion of patients with hospital admission for heart failure (relative risk 1.30, 0.35 to 4.82; table 2). A trend towards an increase in all cause mortality or worsening heart failure was also seen (hazards ratio $1.28,0.51$ to 3.21 .

The pooled effect of the four studies which assessed the effect of thiazolidinediones on all cause mortality $^{\mathrm{w} 1 \mathrm{w} 3 \mathrm{w} 7 \mathrm{w} 8}$ suggests that treatment with thiazolidinediones may be associated with reduced all cause mortality compared with other treatments (pooled odds ratio $0.83,0.71$ to $0.97 ; \mathrm{I}^{2}=52 \% ; \mathrm{P}=0.10$ ), although moderate heterogeneity was observed (fig 3 ). Similarly, the pooled effect on hospital admission for heart failure suggests that thiazolidinediones may be associated with an increased risk of such admission compared with other treatments $(1.13 ; 1.04$ to 1.22 ; $\mathrm{I}^{2}=0 \% ; \mathrm{P}=0.004$; fig 4). ${ }^{\mathrm{w} 1 \mathrm{w} 3 \mathrm{w} 7 \mathrm{w} 8}$ All studies evaluating 
treatment with thiazolidinediones were of good methodological quality (box). ${ }^{\text {w1 w3 w7 w8 }}$ For all cause mortality, although the size and direction of effect estimates varied among studies, we found no consistent pattern of effect in relation to study quality. Similar effect estimates were seen for all studies regardless of quality with respect to hospital admission for heart failure.

\section{Sulfonylureas}

Few studies formally evaluated treatment with sulfonylureas as an independent exposure group. In the studies evaluating other oral treatments, however, sulfonylureas were used in about $55 \%$ of all patients in the main comparator groups $(\mathrm{n} \approx 11000)$. As a result, treatment with sulfonylurea was well represented in all of the studies evaluating oral antidiabetic agents included in our review.

Apart from the effect of sulfonylureas relative to metformin use already mentioned, ${ }^{\text {w2 }}$ only one other study looked at sulfonylureas. ${ }^{\mathrm{w} 1}$ After multivariate analysis, no increased risk of mortality at one year was seen for patients receiving sulfonylureas compared with patients receiving other insulin secretagogues, alpha glucosidase inhibitors, metformin, thiazolidinediones, or insulin $(0.99 ; 0.91$ to 1.08$)$.

\section{DISCUSSION}

Heart failure is a common comorbidity in patients with diabetes. Despite the high morbidity and mortality associated with the disease, our systematic review found few studies that formally compared antidiabetic drugs in this important population. Although several studies have evaluated the incidence of heart failure associated with the use of various antidiabetic agents, ${ }^{3823-26}$ our review focused solely on the impact of such treatments in people with comorbid heart failure and diabetes. Of the eight studies included in this review, most studies were observational and there was only one randomised controlled trial, which was not designed to evaluate clinical outcomes. All studies were published in the past two years, and focused on use of insulin, thiazolidinediones, or metformin.

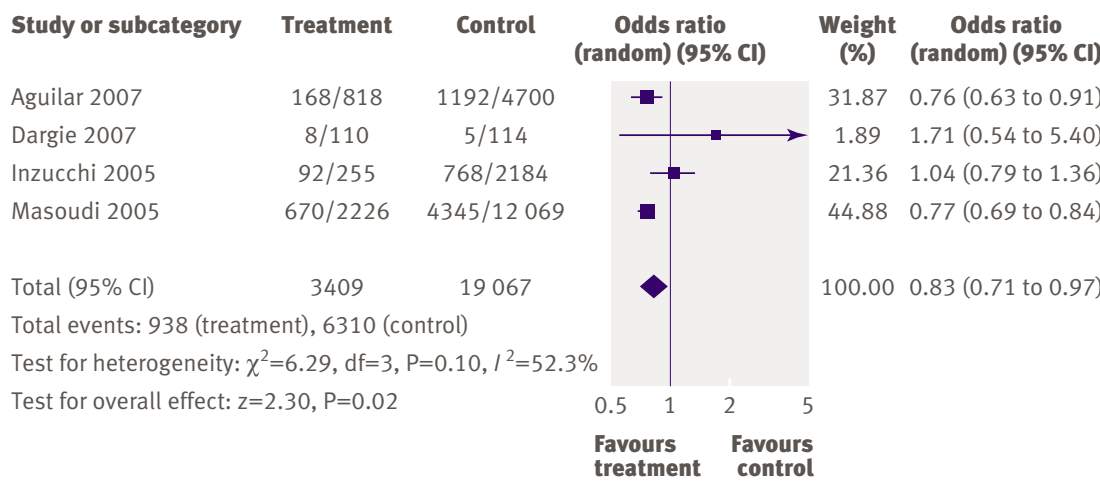

Fig 3 | Pooled odds ratio for thiazolidinediones compared with other treatments for all cause mortality
Insulin

In the four studies that specifically evaluated the use of insulin treatment, three suggested an increase in mortality, and one reported no association with mortality. Statistical heterogeneity precluded formal meta-analysis. Importantly, in two of the studies reporting increased mortality, there was no multivariate adjustment for the comparison between insulin and noninsulin treatments in patients with diabetes. Furthermore, none of the studies randomised patients to insulin or non-insulin treatment. As a result, it is difficult to tell whether this is a true adverse effect of insulin or whether it is simply confounding by indication. Treatment with insulin in these studies may well have been a marker for more advanced diabetes or vascular disease (or both). ${ }^{\mathrm{w} 6}$ Thus, treatment with insulin may not, in itself, be associated with an increase in adverse effects in this population. Indeed, in one study that adjusted extensively for clinically important variables and compared insulin with other antidiabetic agents, insulin was not associated with an increased risk of mortality. ${ }^{\mathrm{w}}$

\section{Metformin}

Historically, metformin has been considered absolutely contraindicated in patients with heart failure who need drug treatment because of concerns about lactic acidosis. Recently, however, the US Food and Drug Administration has removed the heart failure contraindication from the packaging of metformin (Glucophage and Glucophage XR), although a strong warning for the cautious use of metformin in this population still exists. ${ }^{27}$ The true prevalence of metformin use in patients with heart failure is not known, but published studies suggest $10-25 \%$ of patients receiving metformin have comorbid heart failure. ${ }^{28-30}$ Despite the concerns, our analysis revealed that treatment with metformin may be associated with lower mortality rates, although statistical heterogeneity precluded formal meta-analysis. Furthermore, no study found an increase in adverse events with metformin and the results of both studies that evaluated all cause hospital admissions in metformin users suggested that this drug is associated with a lower rate of all cause hospital admission than other antidiabetic drugs.

\section{Thiazolidinediones}

Thiazolidinediones are also relatively contraindicated in patients with New York Heart Association class III or IV disease because of concerns about fluid retention, which may worsen symptoms of heart failure. ${ }^{31}$ Yet, the pooled effects for mortality suggest that thiazolidinediones may be associated with reduced mortality, although the results should be interpreted cautiously as moderate statistical heterogeneity was present. The only randomised controlled trial showed a trend towards an increased risk of mortality with thiazolidinediones; however, the study was not specifically designed to assess clinical outcomes and $62(28 \%)$ patients withdrew from the study. ${ }^{\mathrm{w} 7}$ As a result, the study was underpowered to detect any differences in 


\begin{tabular}{|c|c|c|c|c|c|c|c|}
\hline Study or subcategory & Treatment & Control & \multicolumn{3}{|c|}{$\begin{array}{c}\text { Odds ratio } \\
\text { (random) }(95 \% \mathrm{Cl})\end{array}$} & \multirow{2}{*}{$\begin{array}{c}\text { Weight } \\
\text { (\%) } \\
16.73\end{array}$} & \multirow{2}{*}{$\begin{array}{c}\text { Odds ratio } \\
\text { (random) }(\mathbf{9 5 \%} \mathbf{~ C l}) \\
1.05(0.86 \text { to } 1.28)\end{array}$} \\
\hline Aguilar 2007 & $134 / 818$ & $741 / 4700$ & & -4 & & & \\
\hline Dargie 2007 & $5 / 110$ & $4 / 114$ & 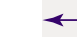 & & & 0.38 & $1.31(0.34$ to 5.01$)$ \\
\hline Inzucchi 2005 & $139 / 255$ & $1083 / 2184$ & & $\rightarrow$ & & 9.98 & 1.22 (0.94 to 1.58$)$ \\
\hline Masoudi 2005 & $1505 / 2226$ & $7821 / 12069$ & & $\square$ & & 72.92 & 1.13 (1.03 to 1.25$)$ \\
\hline Total $(95 \% \mathrm{Cl})$ & 3409 & 19067 & & $\downarrow$ & & 100.00 & $1.13(1.04$ to 1.2 \\
\hline \multirow{2}{*}{\multicolumn{8}{|c|}{$\begin{array}{l}\text { Total events: } 1783 \text { (treatment), } 9649 \text { (control) } \\
\text { Test for heterogeneity: } \chi^{2}=0.93, \mathrm{df}=3, \mathrm{P}=0.82, I^{2}=0 \%\end{array}$}} \\
\hline & & & & & & & \\
\hline \multirow{2}{*}{\multicolumn{3}{|c|}{ Test for overall effect: $z=2.86, P=0.004$}} & 0.5 & 1 & 2 & 5 & \\
\hline & & & $\begin{array}{l}\text { Favc } \\
\text { trea }\end{array}$ & nt & & & \\
\hline
\end{tabular}

Fig 4 | Pooled odds ratio for thiazolidinediones compared with other treatments on hospital admission for heart failure evaluated the effects of oral antidiabetic agents as monotherapy. ${ }^{\text {w2 }}$ Contamination of comparison groups as a result of the use of multiple antidiabetic drugs is a possibility in the other two studies. ${ }^{\text {w1 w3 }}$

\section{Sulfonylureas}

Only two studies specifically evaluated sulfonylureas as an independent exposure. ${ }^{\mathrm{w} 1 \mathrm{w} 2}$ One study found that sulfonylurea monotherapy may be associated with worse outcomes, ${ }^{\text {w2 }}$ whereas the other did not. ${ }^{\text {w1 }}$ The discrepancy may partly be due to the comparator groups used in the studies. The first study compared sulfonylurea monotherapy with metformin, which has been shown to be beneficial in all similar studies, while the second compared sulfonylurea exposure (alone or in combination) with treatments that did not specifically include metformin. In the first study, it is not clear whether the risk estimates were a result of an adverse effect of sulfonylureas, a beneficial effect of metformin, or confounding by indication. Although these results are consistent with other studies evaluating sulfonylureas, ${ }^{37-40}$ a recent meta-analysis has indicated that these drugs are not associated with an increase in cardiovascular events. ${ }^{41}$ Given the current controversy surrounding the use of sulfonylureas in patients with pre-existing cardiovascular disease, ${ }^{42}$ more research is needed to determine the true impact of these drugs in people with diabetes and heart failure.

\section{Limitations}

Inherent to any systematic review is the potential for publication or selection bias. Studies that may have evaluated the use of antidiabetic agents in patients with heart failure as part of a stratified or secondary analysis may not have been identified using standard search strategies. However, manual searches and contact with primary authors of the included studies provided no extra articles. Any relevant articles are therefore unlikely to have been missed. Secondly, the included studies were mainly observational and only one study randomised patients to different antidiabetic drugs. As a result, the effects of unmeasured confounding variables could not be fully explored and this may be a limitation of most of the reported studies.

\section{Conclusions}

Our results suggest that of the current antidiabetic agents, metformin is the only one not associated with any measurable harm in people with diabetes and heart failure and is associated with reduced mortality. Given the large number of people affected with diabetes and heart failure and the fact that this population is expected to increase rapidly, evidence on how to optimally control glycaemic levels in this population is urgently needed. It is therefore imperative that research be undertaken to determine the optimal approach for glycaemic control in patients with heart failure. Ideally, this research should be a randomised controlled trial which includes the use of metformin or thiazolidinedione in patients with heart failure and 
Details of the eight included studies of antidiabetic agents for treating diabetes with heart failure

\section{Murcia et al (2004) $)^{\text {w6 }}$}

Design-Post hoc subgroup analysis of randomised controlled trial (SAVE; n=496)

Inclusion criteria-Diabetes, between 21 and 80 years of age, left ventricular ejection fraction $\leq 40 \%$ after myocardial infarction

Exclusion criteria-Contraindication to angiotensin converting enzyme inhibitors or need to treat heart failure or hypertension, creatinine $>221 \mathrm{mmol} / \mathrm{l}$; unstable illness; active ischaemia

Agents evaluated-Insulin

Method of analysis-Multivariate Cox proportional hazards regression Covariates included in analysis-Age, sex, left ventricular ejection fraction, previous myocardial infarction, killip class $\geq I$, thrombolytic treatment, use of $\beta$ blockers, and captopril assignment

Duration-Mean 3.5 years

Methodological quality checklist score-44\%

Potential limitations and threats to validity-Selection bias (data derived from randomised controlled trial in patients after myocardial infarction). Uncertain drug exposure (drug use defined at start of trial, exposure to drug throughout follow-up uncertain). Confounding by severity of diabetes (no data on glucose control, duration of diabetes). Limited adjustment for clinical data. No data on type of oral antidiabetic agents used

Pocock et al (2006) ${ }^{\mathrm{w} 4}$

Design-Post hoc subgroup analysis of randomised controlled trial CHARM $(n=2160)$

Inclusion criteria-18 years or older, symptomatic heart failure (New York Heart Association class II-IV) of at least four weeks' duration

Exclusion criteria-Creatinine $\geq 265 \mu \mathrm{mol} / \mathrm{l}, \mathrm{K}^{+}>5.5 \mathrm{mmol} / \mathrm{l}$, bilateral renal stenosis, symptomatic hypotension, women of childbearing potential not receiving contraceptives, critical aortic or mitral stenosis, myocardial infarction, stroke or open heart surgery in the previous four weeks, use of angiotensin receptor blockers in previous two weeks, any non-cardiac disease likely to limit survival to two years

Agents evaluated-Insulin

Method of analysis-Univariate

Covariates included in analysis-No covariate adjustment

Duration-Median 37.7 months

Methodological quality checklist score-41\%

Potential limitations and threats to validity-Confounding by severity of diabetes (no data on glucose control, duration of diabetes). No data on type of oral antidiabetic agents used. Uncertain exposure (criteria used to define "insulin use" not stated; no data on duration of drug use; exposure to drug throughout follow-up uncertain). Selection bias (data derived from randomised controlled trial). No adjusted results comparing insulin with other treatments in patients with diabetes

Smooke et al (2005) ${ }^{\mathrm{w5}}$

Design-Prospective cohort study $(n=132)$

Inclusion criteria-Consecutive patients referred to specialty clinic to manage heart failure or evaluate them for a heart transplant because of systolic dysfunction (left ventricular ejection fraction $40 \%$ ) from 1

January 2000 to 30 January 2003

Exclusion criteria-No exclusions reported

Agents evaluated-Insulin

Method of analysis-Univariate

Covariates included in analysis-No covariate adjustment

Duration-Mean 11.7 months

Methodological quality checklist score-63\%

Potential limitations and threats to validity-Small sample size initially and $15 \%$ lost to follow-up (few patients left to evaluate for two year outcome). Uncertain exposure (no data on duration of drug use; exposure to drug throughout follow-up uncertain). Significant baseline differences (incomplete adjustment because of small sample size). No adjusted results comparing insulin and non-insulin treatments in patients with diabetes. Short duration of follow-up (mean 11.7 months). Results limited to a select population of patients (advanced heart failure patients only)

Masoudi et al (2005) ${ }^{\mathrm{w} 1}$

Design-Retrospective cohort study $(n=16417)$

Inclusion criteria-Patients with diabetes receiving antidiabetic agents upon discharge with a principal discharge diagnosis of heart failure

Exclusion criteria-Over 65 years of age, died during hospital admission, unknown date of death, unknown readmission data, discharge to a hospice, no drug treatment for diabetes at discharge

Agents evaluated-Insulin, metformin, thiazolidinediones, sulfonylurea

Method of analysis-Stepwise multivariate Cox proportional hazards regression

Covariates included in analysis-Demographics (age, sex, race); cardiac history (history of myocardial infarction, hypertension, coronary artery disease, percutaneous transluminal coronary angioplasty; noncardiovascular history (admission source, mobility, cerebral vascular accident, chronic pulmonary disease, urinary incontinence, dementia); clinical characteristics at admission (systolic blood pressure, respiratory rate, heart failure, $\mathrm{Na}^{+}$, glucose, blood urea nitrogen test, creatinine, white blood cell count, haematocrit); hospital course (atrial fibrillation, heart failure or pulmonary oedema on admission, cardiac catheterisation, percutaneous transluminal coronary angioplasty, coronary artery bypass surgery, complications of diabetes); discharge prescriptions; severity of diabetes; sampling time frame

Duration-Not reported

Methodological quality checklist score-50\%

Potential limitations and threats to validity-Uncertain exposure (cohort created on the basis of drug prescribed at discharge; exposure to drug throughout follow-up uncertain). Short duration of follow-up (outcomes at one year). Results limited to a select population of patients ( $>65$ years of age)

Inzucchi et al (2005) ${ }^{\text {w3 }}$

Design-Retrospective cohort study $(n=2875)$

Inclusion criteria-Patients with diabetes receiving antidiabetic agents upon discharge from hospital for myocardial infarction

Exclusion criteria-Unconfirmed myocardial infarction, long term haemodialysis, over 65 years of age, died during hospital stay, unknown date of death, unknown readmission data, discharge to a hospice, transferred to another hospital, left against medical advice, no drug treatment for diabetes at discharge

Agents evaluated-Metformin, thiazolidinediones

Method of analysis-Stepwise multivariate Cox proportional hazards regression

Covariates included in analysis-Potential covariates included demographics (age, sex, race); cardiac history (history of heart failure, myocardial infarction, hypertension, revascularisation); noncardiovascular history (admission source, mobility, cerebral vascular accident, chronic pulmonary disease, urinary incontinence, dementia) clinical characteristics at admission (systolic blood pressure, respiratory rate, heart failure, $\mathrm{Na}^{+}$, glucose, blood urea nitrogen test, creatinine, white blood cell count, haematocrit); hospital course (atrial fibrillation, heart failure or pulmonary oedema on admission, cardiac catheterisation, percutaneous transluminal coronary angioplasty, coronary artery bypass surgery, complications of diabetes); discharge prescriptions; severity of diabetes; sampling time frame; patient clustering by hospital

Duration-Not reported

Methodological quality checklist score-47\% 
Potential limitations and threats to validity-Selection bias (over 65 years of age, after myocardial infarction only). Small sample size (few subjects in left ventricular dysfunction subgroup). Uncertain exposure (cohort created on the basis of on drugs prescribed at discharge; exposure to drug throughout follow-up uncertain). Short duration of follow-up (outcomes at one year)

Eurich et al (2005) ${ }^{\mathrm{w} 2}$

Design-Retrospective cohort study ( $n=1833)$

Inclusion criteria-New users of oral antidiabetic agents with incident onset heart failure

Exclusion criteria-Insulin use, prevalent heart failure (diagnosis of heart failure before starting oral antidiabetic agents)

Agents evaluated-Metformin, sulfonylurea

Method of analysis-Multivariate Cox proportional hazards regression Covariates included in analysis-Age, sex, modified chronic disease score, prescription drugs affecting outcomes in people with diabetes or heart failure (or both), total number of visits to doctor before diagnosis of heart failure, propensity score (not included in final models)

Duration-Mean 2.5 years

Methodological quality checklist score- $50 \%$

Potential limitations and threats to validity-Selection bias (uncertain diagnostic accuracy of heart failure in doctor's service file; insulin users excluded). Uncertain exposure (cohort created based on a single prescription for antidiabetic drugs; exposure to drug throughout followup uncertain; combination therapy not necessarily concurrent therapy). Confounding by severity of diabetes or heart failure (no clinical data or functional status). Small sample size (only 208 in metformin monotherapy cohort)

Dargie et al (2007) ${ }^{\mathrm{w} 7}$

Design-Randomised controlled trial $(n=224)$

Inclusion criteria-Fasting blood glucose $\geq 7 \mathrm{mmol} / \mathrm{l}$, stable New York Heart Association class I/II, left ventricular ejection fraction $\leq 45 \%$, treatment with angiotensin converting enzyme inhibitors or angiotensin receptor blockers and diuretic if New York Heart Association class II
Exclusion criteria-Body mass index more than 35, creatinine clearance $\varangle 40 \mathrm{ml} / \mathrm{min}$, hepatic disease, anaemia

Agents evaluated-Thiazolidinediones

Method of analysis-Cox proportional hazards regression

Covariates included in analysis-None

Duration-One year

Methodological quality checklist score-66\%

Potential limitations and threats to validity-Baseline characteristics were not fully matched between placebo and treatment group. Small sample size and few clinical events (inadequate power to detect clinical differences). High withdrawal rate (28\%)

Aguilar et al (2007) w8

Design-Retrospective cohort study ( $n=7147)$

Inclusion criteria-Patients of the Veterans Association external peer review programme who had diabetes and were prescribed hypoglycaemic drugs

Exclusion criteria-Treatment with metformin in control group

Agents evaluated-Thiazolidinediones

Method of analysis-Stepwise multivariate Cox proportional hazards regression

Covariates included in analysis-Age, sex, body mass index, left ventricular ejection fraction, glomerular filtration rate, haemoglobin, hyponatraemia, glycated haemoglobin, race, previous diabetic complications, atrial fibrillation, heart failure related drugs, previous hospital admission for heart failure, hypertension, myocardial infarction, cancer, chronic obstructive pulmonary disease, peripheral vascular disease, psychiatric disorders, liver disease, rheumatic disease, medical school affiliation, other antidiabetic drugs

Duration-Not reported

Methodological quality checklist score- $50 \%$

Potential limitations and threats to validity-Selection bias (metformin users excluded from control group but not treatment group). Uncertain exposure (cohort created on the basis of 120 day window around index outpatient visit; exposure to drug throughout follow-up uncertain). Short duration of follow-up (outcomes at two years) diabetes. Furthermore, this trial should be aimed at evaluating the effect of these treatments on glycaemic control and its relation to long term outcomes, as well as the effect of these treatments on morbidity and mortality in people with heart failure and diabetes.

Contributors: DTE, FAM, DFB, SRM, RTT, and JAJ helped plan and design the study. DTE, DFB, JV, and JAJ collected the data. DTE conducted the statistical analyses. All authors had access to the data and helped interpret the data. DTE wrote the first draft of the paper. All authors reviewed and revised the paper for important intellectual content and approved the version. DTE led the study, is lead author, and is guarantor.

Funding: DTE held a doctoral research award with Canadian Institutes for Health Research (CIHR). SRM and FAM are new investigators with CIHR and are population health investigators with the Alberta Heritage Foundation for Medical Research (AHFMR). FAM and RTT hold the Merck Frosst/Aventis chair in patient health management. JAJ holds a Canada Research chair in diabetes

\section{WHAT IS ALREADY KNOWN ON THIS TOPIC}

Diabetes is a common comorbidity in people with heart failure and predicts worse outcomes The best way to achieve glycaemic control in patients with diabetes and heart failure is unclear

\section{WHAT THIS STUDY ADDS}

Current evidence suggests that metformin is the only antidiabetic agent not associated with any measurable harm in patients with diabetes and heart failure health outcomes, is a health scholar supported by AHFMR, and is chair of a new emerging team (NET) grant to the Alliance for Canadian Health Outcomes Research in Diabetes (ACHORD). The ACHORD NET grant is sponsored by the Canadian Diabetes Association, the Heart and Stroke Foundation of Canada, The Kidney Foundation of Canada, the CIHR (Institute of Nutrition, Metabolism and Diabetes) and the CIHR (Institute of Circulatory and Respiratory Health). The study sponsors played no role in study design or conduct; collection, analysis, interpretation of data; writing of the report; or in the decision to submit the paper for publication.

Competing interests: None declared.

Ethical approval: Not required.

1 Padwal R, Majumdar SR, Johnson JA, Varney J, McAlister FA. A systematic review of drug therapy to delay or prevent type 2 diabetes. Diabetes Care 2005;28:736-44.

2 Kannel WB, Hjortland M, Castelli WP. Role of diabetes in congestive heart failure: the Framingham study. Am J Cardiol 1974;34:29-34.

3 Nichols GA, Hillier TA, Erbey JR, Brown JB. Congestive heart failure in type 2 diabetes: prevalence, incidence, and risk factors. Diabetes Care 2001;24:1614-9.

4 Stratton IM, Adler AI, Neil HA, Matthews DR, Manley SE, Cull CA, et al. Association of glycaemia with macrovascular and microvascular complications of type 2 diabetes (UKPDS 35): prospective observational study. BMJ 2000;321:405-12.

5 Chae CU, Glynn TJ, Manson JE, Guralnik JM, Taylor JO, Pfeffer MA Diabetes predicts congestive heart failure risk in the elderly. Circulation 1998;98(suppl I):721.

6 Iribarren C, Karter AJ, Go AS, Ferrara A, Liu JY, Sidney S, et al. Glycemic control and heart failure among adult patients with diabetes. Circulation 2001;103:2668-73.

7 Nichols GA, Gullion CM, Koro CE, Ephross SA, Brown JB. The incidence of congestive heart failure in type 2 diabetes: an update. Diabetes Care 2004;27:1879-84. 
8 Nichols GA, Koro CE, Gullion CM, Ephross SA, Brown JB. The incidence of congestive heart failure associated with antidiabetic therapies. Diabetes Metab Res Rev 2005;21:51-7.

9 Bell DS. Heart failure: the frequent, forgotten, and often fatal complication of diabetes. Diabetes Care 2003;26:2433-41.

10 Reis SE, Holubkov R, Edmundowicz D, McNamara DM, Zell KA, Detre KM, et al. Treatment of patients admitted to the hospital with congestive heart failure: specialty-related disparities in practice patterns and outcomes. J Am Coll Cardiol 1997;30:733-8.

11 Amato L, Paolisso G, Cacciatore F, Ferrara N, Ferrara P, Canonico S, et al. Congestive heart failure predicts the development of noninsulin-dependent diabetes mellitus in the elderly. The Osservatorio Geriatrico Regione Campania Group. Diabetes Metab 1997;23:213-8

12 Fonarow GC. Approach to the management of diabetic patients with heart failure: role of thiazolidinediones. Am Heart / 2004;148:551-8.

13 De Groote P, Lamblin N, Mouquet F, Plichon D, McFadden E, Van Belle $E$, et al. Impact of diabetes mellitus on long-term survival in patients with congestive heart failure. Eur Heart J 2004;25:656-62.

14 Ezekowitz J, McAlister FA, Humphries KH, Norris CM, Tonelli M, Ghali WA, et al. The association among renal insufficiency, pharmacotherapy, and outcomes in 6,427 patients with heart failure and coronary artery disease. J Am Coll Cardiol 2004;44:1587-92.

15 Majumdar SR, McAlister FA, Cree M, Chang WC, Packer M, Armstrong PW. Do evidence-based treatments provide incremental benefits to patients with congestive heart failure already receiving angiotensin-converting enzyme inhibitors? A secondary analysis of one-year outcomes from the assessment of treatment with lisinopril and survival (ATLAS) study. Clin Ther 2004;26:694-703.

16 Held C, Gerstein HC, Yusuf S, Zhao F, Hilbrich L, Anderson C, et al. Glucose levels predict hospitalization for congestive heart failure in patients at high cardiovascular risk. Circulation 2007;115:1334-5.

17 Masoudi FA, Inzucchi SE. Diabetes mellitus and heart failure: epidemiology, mechanisms, and pharmacotherapy. Am J Cardiol 2007;99(4A):113B-32B.

18 Eshaghian S, Horwich TB, Fonarow GC. An unexpected inverse relationship between $\mathrm{HbA1c}$ levels and mortality in patients with diabetes and advanced systolic heart failure. Am Heart J 2006;151:91.

19 Downs SH, Black N. The feasibility of creating a checklist for the assessment of the methodological quality both of randomised and non-randomised studies of health care interventions. J Epidemiol Commun Health 1998;52:377-84.

20 Harrison RA, Siminoski K, Vethanayagam D, Majumdar SR. Osteoporosis-related kyphosis and impairments in pulmonary function: a systematic review. J Bone Miner Res 2007;22:447-57.

21 Higgins JPT, Green S, eds. Cochrane handbook for systematic reviews of interventions 4.2.6 (updated September 2006). 2007. www. cochrane.org/resources/handbook/hbook.htm.

22 Pfeffer MA, Swedberg K, Granger CB, Held P, McMurray JJ, Michelson EL, et al. Effects of candesartan on mortality and morbidity in patients with chronic heart failure: the CHARM-Overall programme. Lancet 2003;362:759-66.

23 Karter AJ, Ahmed AT, Liu J, Moffet HH, Parker MM. Pioglitazone initiation and subsequent hospitalization for congestive heart failure. Diabet Med 2005;22:986-93.

24 Maru S, Koch GG, Stender M, Clark D, Gibowski L, Petri H, et al. Antidiabetic drugs and heart failure risk in patients with type 2 diabetes in the UK primary care setting. Diabetes Care 2005;28:20-6.

25 Delea TE, Edelsberg JS, Hagiwara M, Oster G, Phillips LS. Use of thiazolidinediones and risk of heart failure in people with type 2 diabetes: a retrospective cohort study. Diabetes Care 2003;26:2983-9.
26 Kahn SE, Haffner SM, Heise MA, Herman WH, Holman RR, Jones NP et al. Glycemic durability of rosiglitazone, metformin, or glyburide monotherapy. N Engl J Med 2006;355:2427-43.

27 Food and Drug Administration. Product label approval: metformin. 2006. www.fda.gov/cder/foi/label/2006/ 020357s030,021202s015lbl.pdf.

28 Masoudi FA, Wang Y, Inzucchi SE, Setaro JF, Havranek EP, Foody JM, et al. Metformin and thiazolidinedione use in Medicare patients with heart failure. JAMA 2003;290:81-5.

29 Horlen C, Malone R, Bryant B, Dennis B, Carey T, Pignone M, et al. Frequency of inappropriate metformin prescriptions. JAMA 2002;287:2504-5.

30 Holstein A, Nahrwold D, Hinze S, Egberts EH. Contra-indications to metformin therapy are largely disregarded. Diabet Med 1999;16:692-6.

31 American Society of Health-System Pharmacists. AHFS drug information. Bethesda, MD: American Society of Health-System Pharmacists, 2004.

32 Dormandy JA, Charbonnel B, Eckland DJ, Erdmann E, Massi-Benedetti M, Moules IK, et al. Secondary prevention of macrovascular events in patients with type 2 diabetes in the PROactive study (prospective pioglitazone clinical trial in macrovascular events): a randomised controlled trial. Lancet 2005;366:1279-89.

33 Gerstein HC, Yusuf S, Bosch J, Pogue J, Sheridan P, Dinccag N, et al Effect of rosiglitazone on the frequency of diabetes in patients with impaired glucose tolerance or impaired fasting glucose: a randomised controlled trial. Lancet 2006;368:1096-105.

34 Home PD, Pocock SJ, Beck-Nielsen H, Gomis R, Hanefeld M, lones NP, et al. Rosiglitazone evaluated for cardiovascular outcomes -an interim analysis. N Engl J Med 2007;357:28-38.

35 Nissen SE, Wolski K. Effect of rosiglitazone on the risk of myocardia infarction and death from cardiovascular causes. N Engl J Med 2007;356:2457-71.

36 Yki-Jarvinen $\mathrm{H}$. The PROactive study: some answers, many questions. Lancet 2005;366:1241-2.

37 UK Prospective Diabetes Study Group. Effect of intensive blood glucose control with metformin on complications in overweight patients with type 2 diabetes (UKPDS 34). Lancet 1998;352:854-65.

38 Johnson JA, Majumdar SR, Simpson SH, Toth EL. Decreased mortality associated with metformin use compared to sulfonylurea monotherapy in type 2 diabetes mellitus. Diabetes Care 2002;25:2244-8.

39 Garratt KN, Brady PA, Hassinger NL, Grill DE, Terzic A, Holmes DR Jr. Sulfonylurea drugs increase early mortality in patients with diabetes mellitus after direct angioplasty for acute myocardial infarction. J Am Coll Cardiol 1999;33:119-24.

40 Emslie-Smith AM, Boyle DI, Evans JM, Sullivan F, Morris AD. Contraindications to metformin therapy in patients with type 2 diabetes-a population-based study of adherence to prescribing guidelines. Diabet Med 2001;18:483-8.

41 Gangji AS, Cukierman T, Gerstein HC, Goldsmith CH, Clase CM. A systematic review and meta-analysis of hypoglycemia and cardiovascular events: a comparison of glyburide with other secretagogues and with insulin. Diabetes Care 2007;30:389-94.

42 Simpson SH, Majumdar SR, Tsuyuki RT, Eurich DT, Johnson JA. Dose response relation between sulfonylurea drugs and mortality in type 2 diabetes mellitus: a population-based cohort study. CMAJ 2006;174:169-74.

Accepted: 13 August 2007 